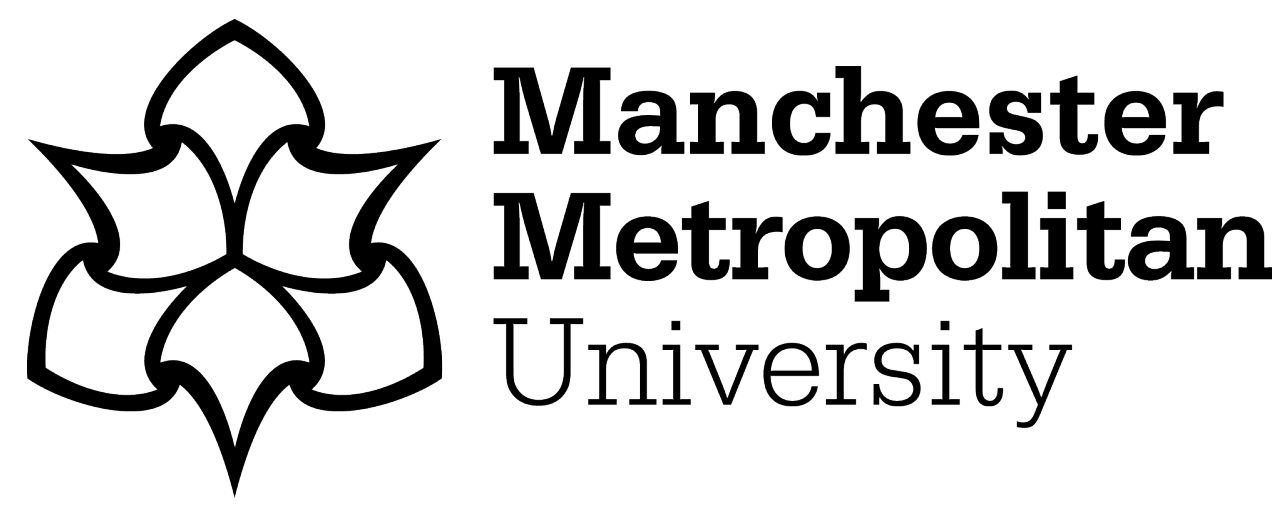

King, Enda, Richter, Chris, Franklyn-Miller, Andy, Daniels, Katherine ORCID logoORCID: https://orcid.org/0000-0001-8134-6764, Wadey, Ross, Jackson, Mark, Moran, Ray and Strike, Siobhán (2020) Corrigendum to "Biomechanical but not timed performance asymmetries persist between limbs 9 months after ACL reconstruction during planned and unplanned change of direction" [J. Biomech. 81 (2018) 93-103]. Journal of Biomechanics, 113. p. 110129. ISSN 0021-9290

Downloaded from: https://e-space.mmu.ac.uk/626891/

Version: Accepted Version

Publisher: Elsevier

DOI: https://doi.org/10.1016/j.jbiomech.2020.110129

Usage rights: Creative Commons: Attribution-Noncommercial-No Derivative Works 4.0

Please cite the published version 


\title{
Corrigendum to "Biomechanical but not timed performance asymmetries persist between limbs 9 months after ACL reconstruction during planned and unplanned change of direction" [J. Biomech. 81 (2018) 93-103]
}

\author{
Enda King ${ }^{\mathrm{a}, \mathrm{b}, *}$, Chris Richter ${ }^{\mathrm{a}, \mathrm{b}}$, Andy Franklyn-Miller ${ }^{\mathrm{a}, \mathrm{c}}$, Katherine Daniels ${ }^{\mathrm{a}}$, Ross Wadey ${ }^{\mathrm{d}}$, Mark Jackson ${ }^{\mathrm{a}}$, \\ Ray Moran ${ }^{a}$, Siobhán Strike ${ }^{b}$ \\ ${ }^{a}$ Sports Medicine Research Department, Sports Surgery Clinic, Santry Demesne, Dublin, Ireland \\ ${ }^{\mathrm{b}}$ Department of Life Sciences, Roehampton University, UK \\ ${ }^{\mathrm{c}}$ Centre for Health, Exercise and Sports Medicine, University of Melbourne, Australia \\ ${ }^{\mathrm{d}}$ School of Sport, Health, and Applied Sciences, St Mary's University, UK
}

The authors regret that the function used to normalise joint moments to body mass contained an error which resulted in incorrect calculation of these variables. Full re-analysis of the corrected data identified small differences from those originally reported in some effect sizes and phase boundaries for the relevant betweenlimb comparisons, but did not affect the conclusions of the study. Corrections to the text, tables and figures are detailed below, with changes to the corrected text highlighted in bold.

\section{Abstract}

The abstract page states that ACLR side effect sizes were $\mathbf{0 . 7 2}$ 0.50. This should read $0.74-0.53$.

\section{Results Section}

3.2.1 Biomechanical differences between limbs:

The original text reads (errors highlighted in bold): The differences with the largest effect size was less internal knee valgus moment on the ACLR limb in the middle of the stance phase (19-85\%; ES 0.72). There was less knee flexion angle (19-84\%; ES 0.57 ), ankle external rotation moment (19-83\%; ES.56), knee external rotation moment (19-82\%; ES 0.54), knee extension moment (15-91\%; ES 0.50) as well as less knee internal rotation angle throughout all of stance phase (0-100\%; ES 0.56) on the ACLR side.

This should read: The differences with the largest effect size was less internal knee valgus moment on the ACLR limb in the middle of the stance phase (19-85\%; ES 0.74). There was less knee flexion angle (19-84\%; ES 0.57), ankle external rotation moment (19-83\%; ES; 0.57), knee external rotation moment (19-82\%; ES 0.54), knee extension moment (15-91\%; ES 0.53) as well as less knee internal rotation angle throughout all of stance phase (0-100\%; ES 0.56) on the ACLR side.

The table below should replace Table 2 .

\begin{tabular}{|c|c|c|c|c|c|c|c|c|}
\hline \multicolumn{9}{|c|}{ Biomechanical differences between limbs (planned and unplanned combined) } \\
\hline Variable & Direction & Start & End & $\begin{array}{l}\text { ACLR } \\
( \pm \text { STD })\end{array}$ & $95 \% \mathrm{CI}$ & $\begin{array}{l}\text { Non-ACLR } \\
( \pm \text { STD })\end{array}$ & $95 \% \mathrm{CI}$ & $\begin{array}{l}\text { Effect } \\
\text { size }\end{array}$ \\
\hline $\begin{array}{l}\text { Knee abduction moment } \\
\quad(\mathrm{Nm} / \mathrm{kg})\end{array}$ & Valgus & 19 & 85 & $0.45(0.42)$ & $0.40-0.50$ & $0.97(0.63)$ & $0.89-1.05$ & 0.74 \\
\hline Knee angle sagittal $\left({ }^{\circ}\right)$ & Flexion & 19 & 84 & $55.3(7.4)$ & $54.4-56.2$ & $60.3(7.5)$ & $59-61$ & 0.57 \\
\hline $\begin{array}{l}\text { Ankle moment transverse } \\
\qquad(\mathrm{Nm} / \mathrm{kg})\end{array}$ & External Rotation & 19 & 83 & $-0.02(0.16)$ & $-0.04-0.00$ & $0.16(0.28)$ & $0.13-0.20$ & 0.57 \\
\hline Knee angle transverse $\left({ }^{\circ}\right)$ & Internal Rotation & 0 & 100 & $16.2(10.2)$ & $14.9-17.4$ & $22.6(10.4)$ & $21.2-23.8$ & 0.56 \\
\hline $\begin{array}{l}\text { Knee moment transverse } \\
(\mathrm{Nm} / \mathrm{kg})\end{array}$ & External Rotation & 19 & 82 & $0.04(0.14)$ & $0.03-0.06$ & $0.20(0.27)$ & $0.16-0.23$ & 0.55 \\
\hline $\begin{array}{l}\text { Knee moment sagittal } \\
(\mathrm{Nm} / \mathrm{kg})\end{array}$ & Extension & 15 & 91 & $1.38(0.51)$ & $1.32-1.44$ & $1.75(0.48)$ & $1.69-1.81$ & 0.53 \\
\hline
\end{tabular}

DOI of original article: https://doi.org/10.1016/j.jbiomech.2018.09.021

* Corresponding author at: Sports Medicine Research Department, Sports Surgery Clinic, Santry Demesne, Dublin, Ireland.

E-mail address: endaking@hotmail.com (E. King). 
The figures below, representing the joint moments, replace those in Appendix A (no changes to joint angles). Knee Moment Frontal

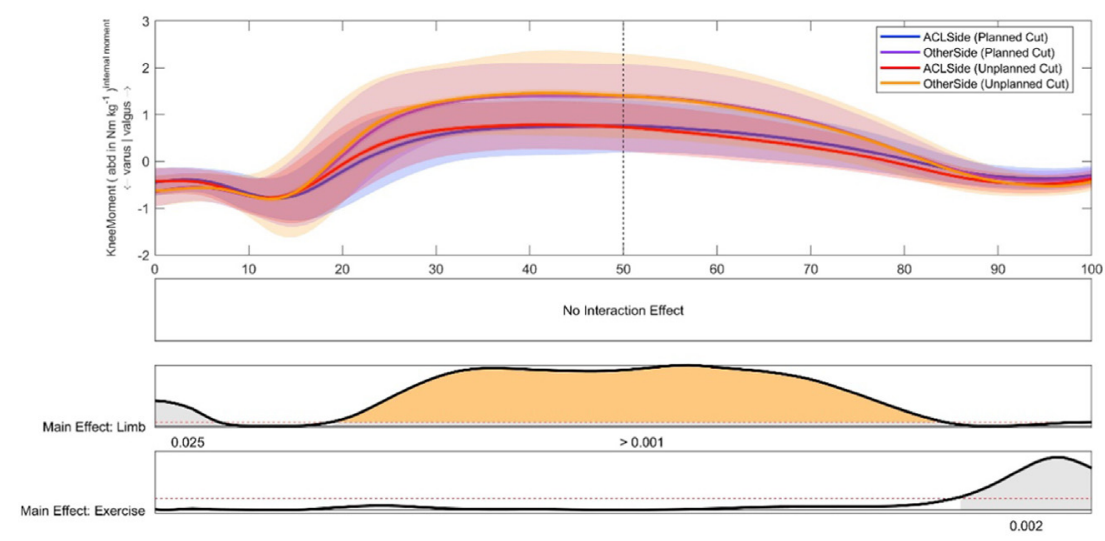

Ankle Moment Transverse

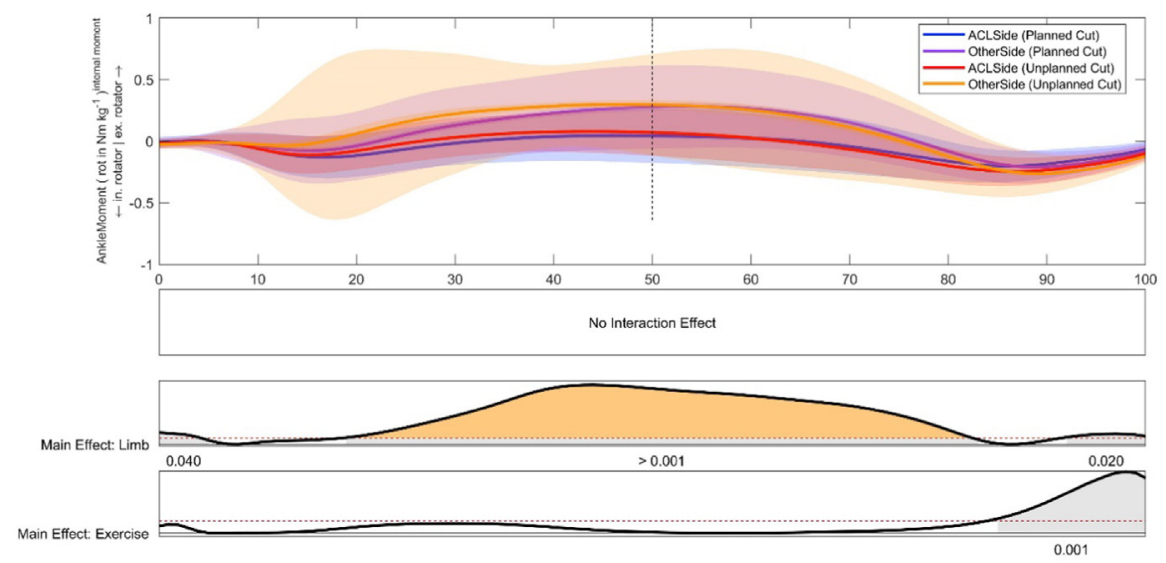

Knee Moment Transverse

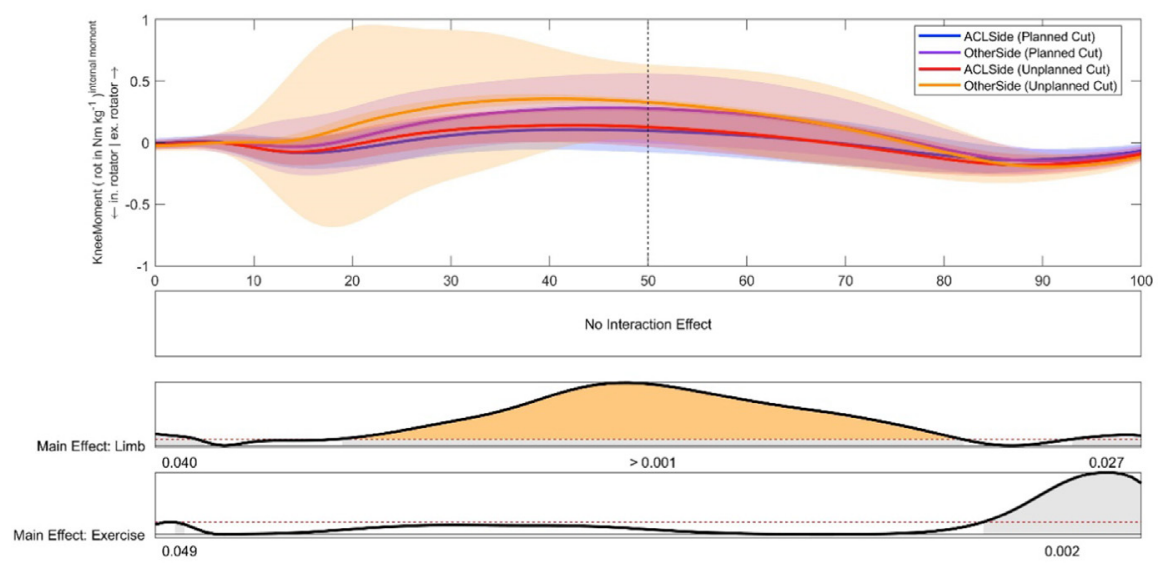


Knee Moment Sagittal
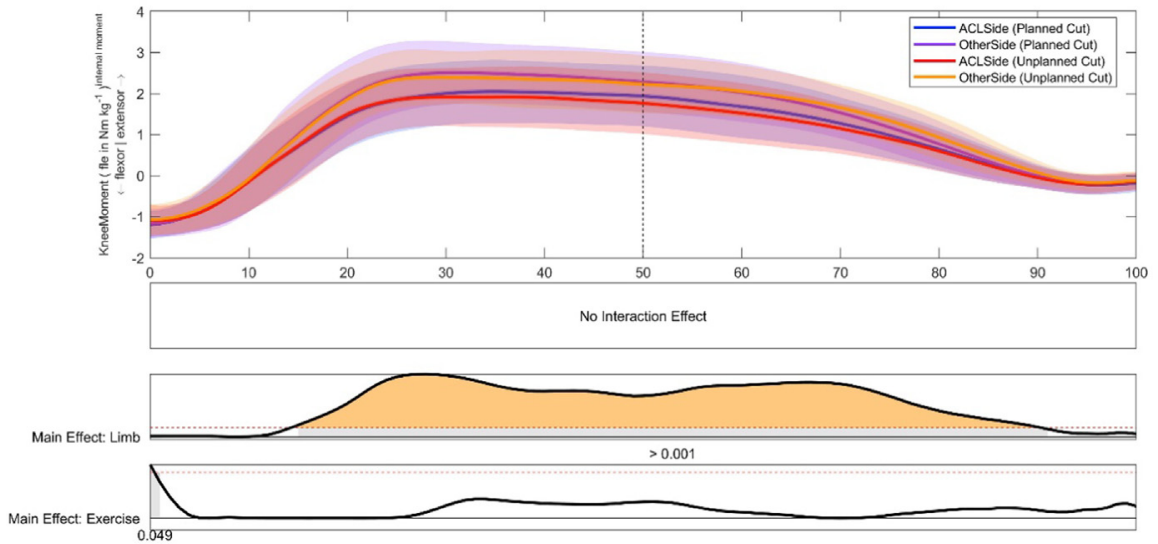

The authors would like to apologise for any inconvenience caused. 